TAVARES, AR; FERREIRA, ML; JOCYS, T; KANASHIRO, S; SILVA, KG. 2016. Urea concentration on vegetative development and nutrition of Cactaceae epiphytic species. Horticultura Brasileira 34: 340-345. DOI - http://dx.doi.org/10.1590/S0102-05362016003006

\title{
Urea concentration on vegetative development and nutrition of Cactaceae epiphytic species
}

\author{
Armando R Tavares ${ }^{1}$; Mauricio L Ferreira' ${ }^{2}$ Teresa Jocys ${ }^{3}$; Shoey Kanashiro ${ }^{1}$; Karina G Silva ${ }^{1}$
}

'Instituto de Botânica, Núcleo de Pesquisa em Plantas Ornamentais (IBt), São Paulo-SP, Brasil; atavares2005@yahoo.com.br; skanashi@ uol.com.br; kazinhavgt@yahoo.com.br; ${ }^{2}$ Universidade Nove de Julho, Departamento de Saúde (Uninove), São Paulo-SP, Brasil; mauecologia@yahoo.com.br; ${ }^{3}$ Instituto Biológico, Centro de Pesquisa e Desenvolvimento de Sanidade Vegetal (IB), São Paulo-SP, Brasil; jocys@biologico.sp.gov.br

\begin{abstract}
Rhipsalis paradoxa, Rhipsalis baccifera and Hatiora salicornioides are epiphytic cacti from the Atlantic Forest. They have a great ornamental potential due to the exotic characteristic of their joints (stems segments). The study aimed to evaluate the growth and development of roots and shoots as well as macronutrient and micronutrient contents in the joints of these species fertilized with different concentrations of urea as a nitrogen source. The study also analyzed the importance of the root system on nitrogen absorption. Plants were weekly irrigated with modified Hoagland \& Arnon solutions with $0,16.7,33.3,49.9$ or $66.6 \mathrm{mM} \mathrm{N}$ applied as urea. After 180 days of cultivation, plants were separated into joints and roots for biometric and biomass measures, as well as macronutrient and micronutrient analysis of joints. The experimental design was randomized blocks, with five treatments, four blocks and five plants per plot, for each species. Data were submitted to analyses of variance and regression. $R$. baccifera showed the highest plant length and number of joints in 29.94 and $40.82 \mathrm{mM} \mathrm{N}$, respectively, $H$. salicornioides showed the highest length and number of joints in 48.29 and $45.68 \mathrm{mM} \mathrm{N}$ respectively. For $R$. paradoxa, the highest length was in $66.6 \mathrm{mM} \mathrm{N}$. The lowest values for plant length and number of joints were observed in the absence of $\mathrm{N}$, for all species. High nitrogen concentrations in the solution increased the $\mathrm{N}$ concentration in joints of $R$. baccifera, $R$. paradoxa and $H$. salicornioides by 24,19 and $13 \mathrm{~g} \mathrm{~N} / \mathrm{kg}$ dry mass, respectively. The roots of epiphytic cacti, besides the function of fixing the plant on substrate (phorophyte), are functional for nutrient absorption, and the best results were obtained in 30.05 to $66.60 \mathrm{mM} \mathrm{N}$ in the nutrient solution.
\end{abstract}

Keywords: Rhipsalis paradoxa, Rhipsalis baccifera, Hatiora salicornioides, nitrogen fertilization, stems and roots, nutrient levels.

\section{RESUMO}

Desenvolvimento vegetativo e nutrição de espécies epífitas de Cactaceae submetidas a diferentes concentrações de ureia

Cactáceas epífitas da Mata Atlântica como Rhipsalis paradoxa, Rhipsalis baccifera e Hatiora salicornioides são utilizadas como plantas ornamentais devido à formação de densos aglomerados de seus artículos (segmentos do caule). O estudo visou avaliar o crescimento e desenvolvimento do sistema radicular e aéreo, e os teores de macro e micronutrientes nos artículos das espécies, submetidas a diferentes concentrações de ureia, bem como analisar a importância do sistema radicular na absorção de nitrogênio. As plantas foram irrigadas semanalmente com soluções modificadas de Hoagland \& Arnon, contendo diferentes concentrações de ureia $(0 ; 16,7 ; 33,3$; 49,9 e 66,6 mM N). Após 180 dias de cultivo, as plantas foram separadas em artículos e raízes para as medidas de biometria e biomassa, além da análise de macro e micronutrientes dos artículos. O delineamento experimental utilizado foi em blocos casualizados com cinco tratamentos, quatro blocos e cinco plantas por parcela, para cada espécie. Os dados foram submetidos à análise de variância e regressão. $R$. baccifera apresentou maior comprimento da planta na concentração de 29,94 mM N e maior número de artículos em 40,82 $\mathrm{mM} \mathrm{N}$ e H. salicornioides apresentou maior comprimento em 48,29 $\mathrm{mM} \mathrm{N}$ e maior número de artículos em 45,68 mM; enquanto que para $R$. paradoxa, os maiores comprimentos foram na dose $66,6 \mathrm{mM}$ $\mathrm{N}$. As espécies apresentaram os menores valores de comprimento e número de artículos na ausência de N. O aumento da concentração de $\mathrm{N}$ no meio de cultivo elevou os teores de $\mathrm{N}$ nos artículos em 24 , 19 e $13 \mathrm{~g} \mathrm{~N} / \mathrm{kg}$ de massa de matéria seca nas espécies $R$. baccifera, $R$. paradoxa e $H$. salicornioides, respectivamente. $\mathrm{O}$ estudo mostrou que as raízes das cactáceas epifíticas, além da função de fixação da planta ao substrato (forófito), são funcionais quanto à absorção de nutrientes e se recomenda a adubação de cactáceas epifíticas com 30,05 a 66,60 mM N na solução nutritiva.

Palavras-chave: Rhipsalis paradoxa, Rhipsalis baccifera, Hatiora salicornioides, adubação nitrogenada, caules e raízes, teores de nutrientes.

(Recebido para publicação em 15 de julho de 2015; aceito em 15 de março de 2016)

(Received on July 15, 2015; accepted on March 15, 2016)

$\mathrm{B}$ razil has the greatest biodiversity in the world. However, deforestation for using the area economically and extraction of plants that can be used commercially cause loss of patent opportunities concerning plants with medical, industrial and ornamental potential. Knowing endemic plant species, mainly those with associated ornamental interest, allows creating conditions for commercial cultivation (Cardoso, 2005). The potential use 
of biodiversity is the result of the appropriate combination of availability of wild materials, technology and market, considering that commercial exploitation of the genetic resources is a diversified activity, including research, development and commercialization of food, drugs, cosmetics, among others (Coradin et al., 2011).

Cactaceae family comprises 124 genera and 1,438 species (Hunt et al., 2006) primarily presenting neotropical distribution (Taylor, 1997). The group has countless adaptations to the arid conditions, however, approximately $15 \%$ of its representatives, about 220 species, are adapted to the epiphytic behavior in humid tropical and subtropical forests (Bauer, 2006), standing out among the 20 families with the greatest number of epiphytes (Kersten, 2010).

In the family, tribe Rhipsalideae has the greatest abundance of holoepiphytes (plants exclusively epiphytic), highlighting the genera Rhipsalis and Hatiora (Calvente, 2010). These genera, from Brazil, have a high number of species with great ornamental potential, especially the formation of dense clusters of pending joints (Souza \& Lorenzi, 2000), as the false Christmas cactus Schlumbergera truncata, among other representatives of this subfamily, which are commercial cultivated (Stancato et al., 2003).

Epiphytes occur in environments with frequent temporal and spatial variations of radiation, water and nutrition supply (Benzing, 1973; Freschi et al., 2010). Considering that roots occupy a small area of the trunk in phorophyte, they do not show high capacity for water and nutrient retention, being exposed to water deficit and discontinuous nutritional supplement (Nobel \& Barrera, 2003).

Epiphytes can be classified in two groups, continuously supplied (CS) epiphytes and pulse supplied (PS) epiphytes, related to moisture source. Based on the characteristics as habit, nutrition, water/carbon ratio, among other aspects; Benzing (1987) considered the epiphytic cacti as belonging to the group of PS epiphytes. Since PS epiphytes occur in certain habitats, they do not need to maintain the typical division between the roots and the aboveground part, necessary to life in soil, the vegetative functions being fused in a single body, whereas other parts lose their function, as for example in Bromeliaceae. The reduction in functionality of the root system, which changes from responsible for water and nutrient absorption to simply plant sustainer on the phorophyte, is especially common in xerophytic forms, and has advantages when compared to the stress and high mortality in Bromeliaceae and Orchidaceae families (Benzing, 1987). However, epiphytic Cactaceae species still have not been studied in relation to adaptations of their vegetative organs, mainly in relation to the function of the root system, besides providing plant anchorage, can be related to water and nutrient absorption.

Ammonium $\left(\mathrm{NH}_{4}^{+}\right)$and nitrate $\left(\mathrm{NO}_{3}^{-}\right)$ are the preferential forms of nitrogen absorbed by the plant roots. Despite organic sources of nitrogen, such as urea, are not the most appropriate for terrestrial plants, for some epiphytes these appear to be important. The bromeliad species Vriesea philippocoburgii and Tillandsia pohliana grown in vitro under a concentration of $8 \mathrm{mM} \mathrm{N}$ showed preference for urea as nitrogen source in comparison to $\mathrm{NO}_{3}{ }^{-}$and $\mathrm{NH}_{4}^{+}$(Mercier et al., 1997). Vriesea gigantea cultivated in vivo also presented the best growth in solution with urea $(5 \mathrm{mM} \mathrm{N})$, when compared to the mixed solution of $\mathrm{NO}_{3}$ and $\mathrm{NH}_{4}^{+}$(Takahashi \& Mercier, 2011).

Thus, this study aimed to evaluate the effect of different concentrations of urea in the development and nutritional status of epiphytic cacti, besides analyzing the importance of the root system in nitrogen absorption in ornamental species of epiphytic cacti Rhipsalis paradoxa, Rhipsalis baccifera and Hatiora salicornioides grown in a greenhouse environment.

\section{MATERIAL AND METHODS}

The vegetative material of Rhipsalis paradoxa, Rhipsalis baccifera and Hatiora salicornioides, used for the experiment, was obtained from plants grown in a collection of epiphytic cacti of Institute of Botany, São Paulo, São Paulo State, Brazil. Joints (modified branches also called cladodes), with $5 \mathrm{~cm}$ approximately, were placed in styrofoam trays with 200 cells, containing washed medium texture sand as substrate. After rooting (180 days), the seedlings were transplanted into 0.8 L black polyethylene pots, containing as substrate medium texture sand $(\mathrm{pH}$ $\mathrm{CaCl}_{2=} 5.3 ; \mathrm{P}_{\text {resin }}=16 \mathrm{mg} / \mathrm{dm}^{3} ; \mathrm{K}_{\text {resin }}=$ $0.3 \mathrm{mmol} / \mathrm{dm}^{3} ; \mathrm{Ca}_{\text {resin }}=2.0 \mathrm{mmol}_{\mathrm{c}} / \mathrm{dm}^{3}$; $\mathrm{Mg}_{\text {resin }}<1 \mathrm{mmol} / \mathrm{dm}^{3} ; \mathrm{H}+\mathrm{Al}_{\mathrm{SMP}}=8.0$ $\mathrm{mmol} / \mathrm{dm}^{3} ;$ sum of basis $=2.3 \mathrm{mmol} /$ $\mathrm{dm}^{3} ; \mathrm{CEC}=10.3 \mathrm{mmol} / \mathrm{dm}^{3} ;$ basis saturation $=22 \% ; \mathrm{B}_{\text {hot water }}<0.1 \mathrm{mg} / \mathrm{dm}^{3}$; $\mathrm{Cu}_{\text {DTPA }}<0.4 \mathrm{mg} / \mathrm{dm}^{3} ; \mathrm{Fe}_{\text {DTPA }}=6.0 \mathrm{mg} /$ $\mathrm{dm}^{3} ; \mathrm{Mn}_{\text {DTPA }}<0.5 \mathrm{mg} / \mathrm{dm}^{3} ; \mathrm{Zn}_{\text {DTPA }}=0.4$ $\mathrm{mg} / \mathrm{dm}^{3}$ ), washed with distilled water which was then autoclaved.

The treatments consisted of applying $50 \mathrm{~mL}$ of Hoagland nutrient solution (Hoagland \& Arnon, 1950), modified (with no $\mathrm{KNO}_{3}$ and $\mathrm{Ca}\left(\mathrm{NO}_{3}\right)_{2} .5 \mathrm{H}_{2} \mathrm{O}$ and addition of $0.49 \mathrm{~g} \mathrm{MgSO}_{4} .7 \mathrm{H}_{2} \mathrm{O} / \mathrm{L}, 0.37$ $\mathrm{g} \mathrm{KCl} / \mathrm{L}$ and $0.74 \mathrm{~g} \mathrm{CaCl}_{2} \cdot 2 \mathrm{H}_{2} \mathrm{O} / \mathrm{L}$ ) and then adding urea in concentrations of $0 ; 16.7 ; 33.3 ; 49.9$ or $66.6 \mathrm{mM} \mathrm{N}$. The solutions were applied in the substrate $(50 \mathrm{~mL})$, manually, using a beaker (the plant shoot was not wet), at 9 a.m. The plants were cultivated in a greenhouse with transparent polyethylene plastic covering with average irradiance of $170 \mu \mathrm{mol} / \mathrm{m}^{2} / \mathrm{s}$, average temperature of $27.5^{\circ} \mathrm{C}$ and sprinkler irrigation (Microsprinkler NaanDanJain ${ }^{\circledR}$ Modular, flow $141 \mathrm{~L} / \mathrm{h}$ ) twice-daily regimens of 15 minutes. The analysis of water used in irrigation showed: $\mathrm{pH}=7.7 ; \mathrm{K}=0.07$ $\mathrm{mmol}_{\mathrm{c}} / \mathrm{L} ; \mathrm{Ca}=0.320 \mathrm{mmol}_{\mathrm{c}} / \mathrm{L} ; \mathrm{Mg}=$ $0.060 \mathrm{mmol}_{\mathrm{c}} / \mathrm{L} ; \mathrm{Cl}=0.960 \mathrm{mmol}_{\mathrm{c}} / \mathrm{L}$; $\mathrm{Na}=0.100 \mathrm{mmol}_{\mathrm{c}} / \mathrm{L} ; \mathrm{CO}_{3}=0.000$ $\mathrm{mmol}_{\mathrm{c}} / \mathrm{L} ; \mathrm{HCO}_{3}=0.420 \mathrm{mmol}_{\mathrm{c}} / \mathrm{L} ; \mathrm{RAS}$ (rate of sodium absorption $)=0.23$ and $\mathrm{EC}=0.080 \mathrm{dS} / \mathrm{m}$.

The experiment was carried out for 180 days, when the plants were removed from the pots and washed in running water. The plants were sectioned into shoot and roots. The variables length of the plant (from the base to the apex of the last joint, $\mathrm{cm}$ ), number of joints and fresh and dry matter of the joints, roots and total $(\mathrm{g})$ were analyzed. The plant joints $(n=5)$ of the three species, in the treatments $0.0 ; 33.3$ and 66.6 


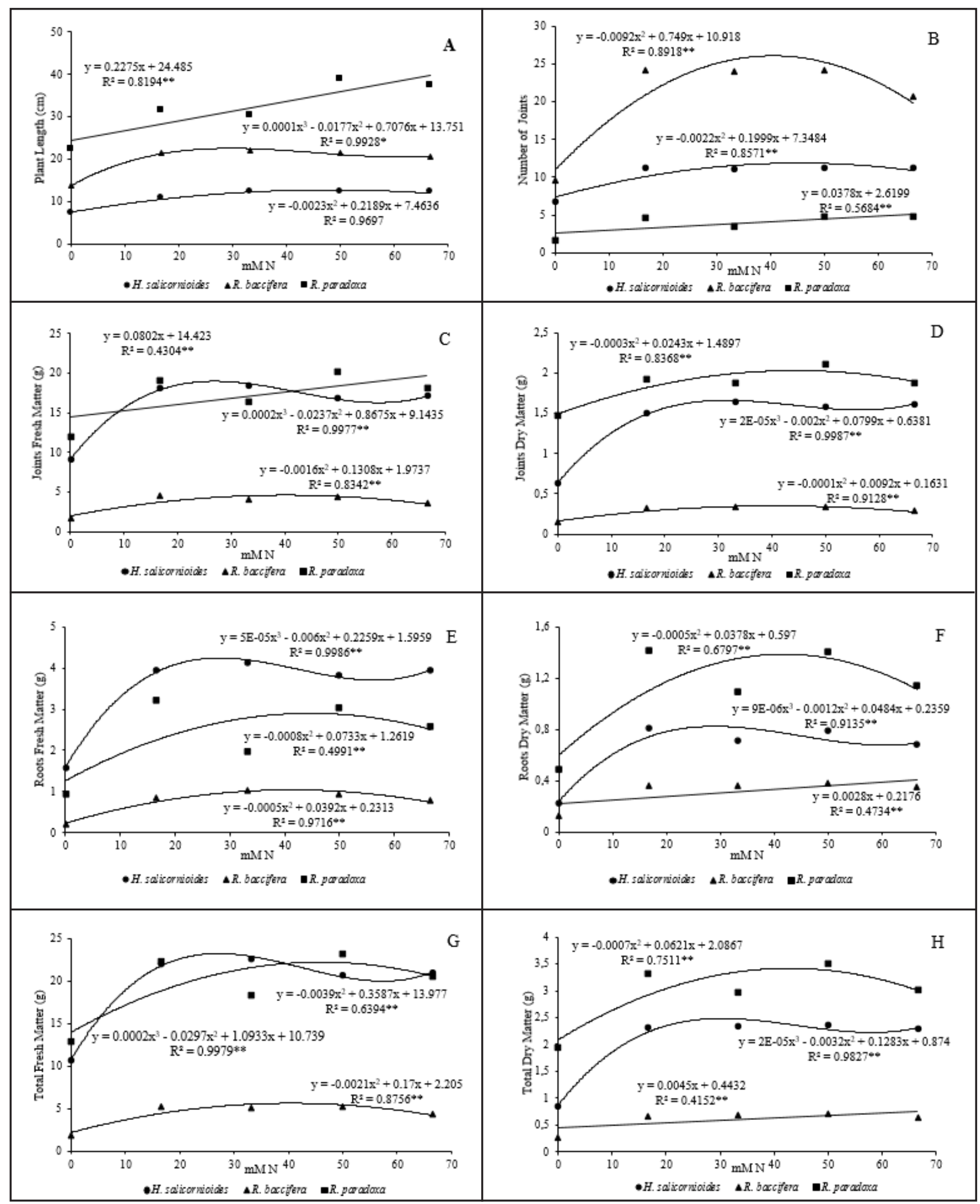

Figure 1. Regression of the variables plant length (A); number of joints (B); joints fresh (C) and dry (D) matter; roots fresh (E) and dry (F) matter; total fresh $(\mathrm{G})$ and dry $(\mathrm{H})$ matter of Rhipsalis baccifera $(\boldsymbol{\Delta})$, R. paradoxa $(\boldsymbol{\bullet})$ and Hatiora salicornioides $(\bullet)$ submitted to different concentrations of urea, after 180 days of experimentation \{regressão das variáveis comprimento da planta (A), número de artículos (B), massa fresca (C) e seca (D) dos artículos, massa fresca (E) e seca (F) da raiz e massa fresca (G) e seca (H) total Rhipsalis baccifera ( $\mathbf{\Delta}$ ), R. paradoxa (•) e Hatiora salicornioides $(\bullet)$ submetidas a diferentes concentrações de ureia, depois de 180 dias de experimentação\}. São Paulo, Instituto de Botânica, 2010.

$* * / *$ significant at $1 \%$ and $5 \%$ of probability, respectively (significativo a $1 \%$ e $5 \%$ de probabilidade, respectivamente). 
$\mathrm{mMN}$ as urea were dried in a forced air circulation oven at temperature of $70^{\circ} \mathrm{C}$, until constant weight was reached. Then, the material was analyzed for macro and micronutrients determination in the Laboratory of Plant Mineral Nutrition at UNESP, Botucatu, São Paulo State, Brazil.

The experimental design was randomized blocks, with four blocks and five plants per plot, for each species. Data were subjected to analysis of variance and regression, using computer statistical program SISVAR.

\section{RESULTS AND DISCUSSION}

R. baccifera showed the highest plant length in concentration of 29.94 $\mathrm{mM} \mathrm{N}$ and the greatest number of joints in $40.82 \mathrm{mM} \mathrm{N}, H$. salicornioides showed the highest plant length in $48.29 \mathrm{mM} \mathrm{N}$ and the greatest number of joints in $45.68 \mathrm{mM} \mathrm{N}$, whereas for $R$. paradoxa, the highest plant length was obtained in $66.6 \mathrm{mM} \mathrm{N}$. The species showed the lowest values for plant length and number of joints in the absence of $\mathrm{N}$ (Figures 1A and 1B). Araújo et al. (2009), studying different concentrations and sources of
$\mathrm{N}$ (calcium nitrate $=0 ; 3.4 ; 6.8 ; 10.2$ and $13.6 \mathrm{mM} \mathrm{N}$ and ammonium nitrate $=0,5.0 ; 10.0 ; 15.0$ and $20.0 \mathrm{mM} \mathrm{N}$ ) in seedlings of Cattleya loddigesii, in vitro cultivated, observed that the number of buds increased in the medium with highest concentrations of nitrate.

Total fresh matter of joints and root of all species increased significantly with $\mathrm{N}$ application. The absence of nitrogen in the solution produced the lowest joints and root fresh matter (Figures 1C, 1E and $1 \mathrm{G})$, differing significantly from the other treatments. $R$. baccifera showed the highest production of dry matter of joints, roots and total in concentrations of $40.92 ; 66.6$ and $66.6 \mathrm{mM} \mathrm{N}, H$. salicornioides in concentrations of 33.28; 30.05 and $30.32 \mathrm{mM} \mathrm{N}$ and $R$. paradoxa in concentrations of 44.77 ; 42.18 and $43.16 \mathrm{mM} \mathrm{N}$, respectively (Figures 1D, 1F and 1H).

The results obtained in biometry and biomass show that doses higher than 44.77 and $30.05 \mathrm{mM} \mathrm{N}$ for $R$. paradoxa and $H$. salicornioides respectively, may be reflected in $\mathrm{N}$ consumption which do not result directly in increasing and in accumulating matter. Absorption and great variation of nutrient contents in the leaves, without presenting an increase in growth or production is called luxury consumption (Faquin, 2002), that, according to Nobel \& Barrera (2004), would be related to the lack of genetic plasticity of newly domesticated cacti or with the slow absorption of nutrients by the roots of these species. Nitrate application in concentrations of $0.8 ; 4$ or $16 \mathrm{mM} \mathrm{N}$ on Opuntia ficus-indica also did not reflect the growth of the species; however Nerd \& Nobel (1995) related the increase of nitrate internal concentrations in plants as a reserve for the growth of new vegetative organs (luxury consumption). Spurway \& Thomas (2001), studying the effect of $\mathrm{N}$ in growth and flowering of epiphytic cactus (Schlumbergera $x$ buckleyi), observed that in the absence of $\mathrm{N}$ the plants showed chlorosis, smaller size and flowering; at intermediate doses (2,370 $\mathrm{g} \mathrm{N} / \mathrm{m}^{3} /$ month) an increase of growth and flowering occurred, whereas high doses of $\mathrm{N}$ contributed to growth inhibition when compared to control $(-19.7 \%$ of dry matter weight) and delayed flowering. The species of cacti submitted to nitrogen fertilization with 8-16 mM N increased photosynthesis, with an increase of $\mathrm{CO}_{2}$ absorption in approximately 400\% (Nobel \& Barrera, 2004).

The works on determination of

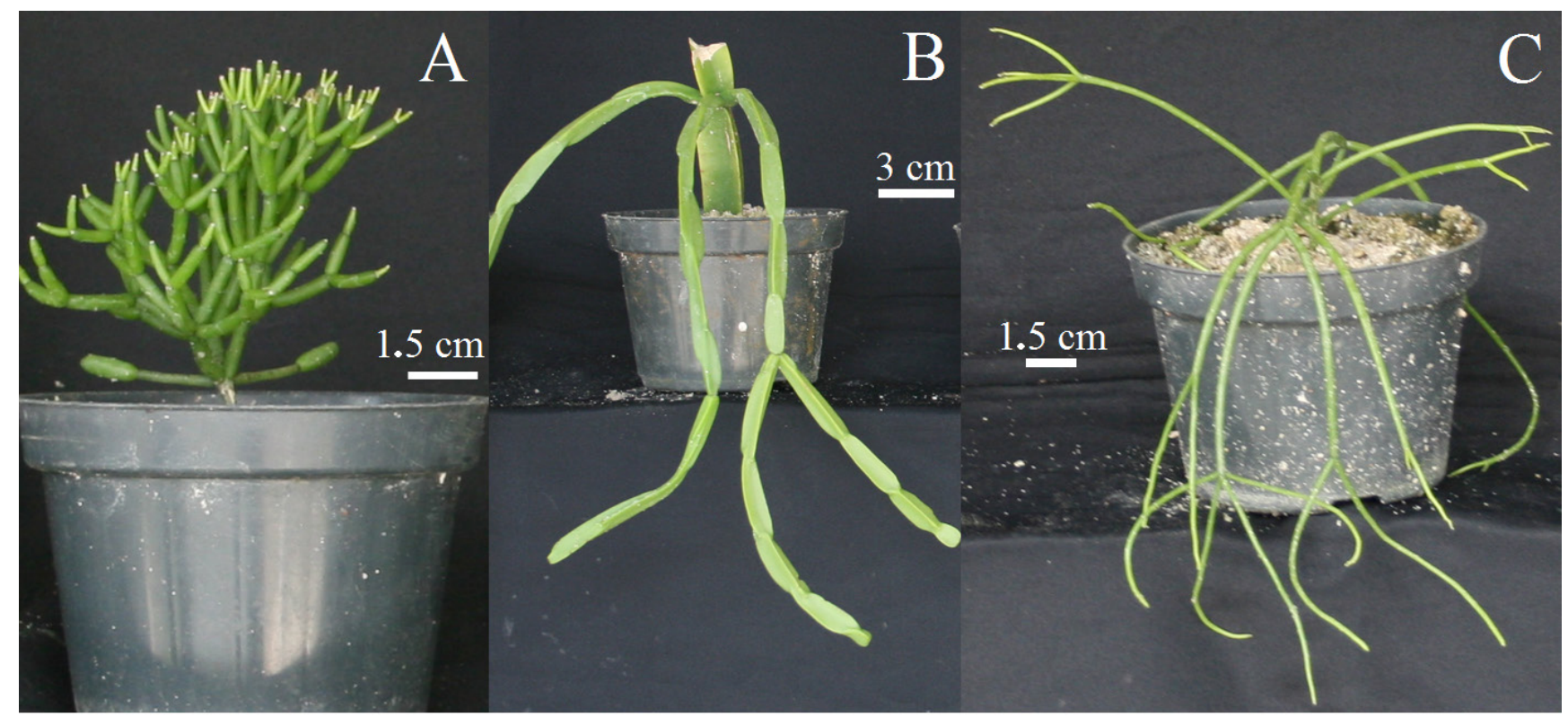

Figure 2. Hatiora salicornioides (A), Rhipsalis paradoxa (B) and Rhipsalis baccifera (C) on treatment $66.6 \mathrm{mM} \mathrm{N}$, after 180 days of experimentation \{Hatiora salicornioides (A), Rhipsalis paradoxa (B) e Rhipsalis baccifera (C) submetidas ao tratamento 66,6 mM N, após 180 dias de experimentação\}. São Paulo, Instituto de Botânica, 2010. 
Table 1. Levels of macro and micronutrients in joints of the species of epiphytic cacti Rhipsalis baccifera, Rhipsalis paradoxa and Hatiora salicornioides, 180 days after transplating to pots (teores de macro e micronutrientes em artículos das espécies das cactáceas epífitas Rhipsalis baccifera, Rhipsalis paradoxa e Hatiora salicornioides, aos 180 dias após transplantio para vasos). São Paulo, Instituto de Botânica, 2010.

\begin{tabular}{|c|c|c|c|c|c|c|c|c|c|c|c|c|}
\hline \multirow{2}{*}{ Species } & \multirow{2}{*}{$\begin{array}{l}\text { Treatment } \\
(\mathrm{mM} \mathrm{N})\end{array}$} & $\mathbf{N}$ & $\mathbf{P}$ & $\mathbf{K}$ & $\mathrm{Ca}$ & Mg & $\mathbf{S}$ & B & $\mathbf{C u}$ & $\mathrm{Fe}$ & Mn & $\mathbf{Z n}$ \\
\hline & & \multicolumn{6}{|c|}{$(\mathrm{g} / \mathrm{kg})$} & \multicolumn{5}{|c|}{$(\mathrm{mg} / \mathrm{kg})$} \\
\hline \multirow{4}{*}{ R. baccifera } & 0.0 & 15 & 5.9 & 62 & 32 & 8.0 & 3.2 & 65 & 8 & 174 & 221 & 75 \\
\hline & 33.3 & 20 & 7.7 & 48 & 21 & 6.3 & 3.3 & 93 & 10 & 250 & 319 & 88 \\
\hline & 66.6 & 24 & 6.1 & 41 & 21 & 6.1 & 3.2 & $\underline{91}$ & 10 & 320 & _331 & 88 \\
\hline & $\overline{0.0}$ & 7 & 2.7 & 34 & $\overline{26}$ & 6.4 & $2 . \overline{8}$ & 51 & 8 & $23 \overline{5}$ & $-\overline{2} 4^{-}$ & 77 \\
\hline \multirow[t]{3}{*}{ R. paradoxa } & 33.3 & 13 & 2.2 & 28 & 18 & 4.5 & 3.1 & 39 & 6 & 296 & 198 & 54 \\
\hline & 66.6 & 19 & 1.9 & 26 & 18 & 5.5 & 2.9 & 38 & 8 & 323 & 279 & 64 \\
\hline & 0.0 & 11 & 3.9 & 55 & 17 & 9.2 & 2.5 & 45 & 3 & 120 & 180 & 58 \\
\hline \multirow[t]{2}{*}{ H. salicornioides } & 33.3 & 11 & 3.7 & 26 & 11 & 5.0 & 2.4 & 61 & 5 & 138 & 239 & 58 \\
\hline & 66.6 & 13 & 2.9 & 26 & 11 & 4.8 & 2.0 & 61 & 6 & 155 & 238 & 59 \\
\hline
\end{tabular}

macro and micronutrients in CAM plants are rare, mainly in Cactaceae species. However, the present study could establish the nutritional requirement of these species, making it a complement of development parameters. Nitrogen contents in joints of the studied species increased with increasing urea doses in the modified Hoagland nutrient solution (HA). R. baccifera, R. paradoxa and $H$. salicornioides (Figure 2) increased $\mathrm{N}$ contents in the joints ranging 1.6; 2.7 and 1.2 times, respectively, at doses 0 to $66.6 \mathrm{mM} \mathrm{N}$ in nutrient solution, responding to the increase of $\mathrm{N}$ concentration in the solution. Few cacti, like Opuntia engelmannii, presented values higher than $20 \mathrm{~g} \mathrm{~N} / \mathrm{kg}$ in the joints (Nobel et al., 1987; Nobel, 2002). This content was observed only for $R$. baccifera at the highest $\mathrm{N}$ dose, which presented $24 \mathrm{~g} \mathrm{~N} / \mathrm{kg}$ in joints. The hemiepiphytic cactus Hylocerus undatus presented $25 \mathrm{~g} \mathrm{~N} / \mathrm{kg}$ in joints (Nobel \& Barrera, 2004) when fertilized with $16 \mathrm{mM} \mathrm{N}$ as nitrate [Hoagland \& Arnon nutrient solution consisting of $\mathrm{NH}_{4} \mathrm{NO}_{3}, \mathrm{KNO}_{3}$ and $\mathrm{Ca}\left(\mathrm{NO}_{3}\right)_{2}$ ], whose values are similar to the ones found in R. baccifera. Nevertheless, Spurway \& Thomas (2001) recommended 34 to 42 $\mathrm{g} \mathrm{N} / \mathrm{kg}$ of aboveground part dry matter of epiphytic cactus (Schlumbergera $x$ buckleyi).

Potassium, $\mathrm{Ca}$ and $\mathrm{Mg}$ contents in the species decreased in the aboveground part with the increase of doses from 0 to 66.6 mM N, with little change in nutrient content between doses of 33.3 and 66.6
mM N (Table 1). Nitrogen in nutrient solution may have an antagonistic effect to potassium, inhibiting the absorption through several mechanisms such as competition between $\mathrm{K}^{+}$and $\mathrm{NH}_{4}^{+}$, the long-distance transport within the plant between $\mathrm{K}^{+}$and $\mathrm{NO}_{3}^{-}$, and absorption and partitioning of $\mathrm{K}$ in plant which can be altered by the form of applied N (Bar Tal, 2011), as the authors also observed in Mulder interaction diagram, modified by Malavolta (1980); however, the authors did not observe an increase of $\mathrm{Mg}$ contents, as a trend indicated in the diagram. The decrease of concentration of $\mathrm{K}$ and $\mathrm{P}$ in pineapple was due to a dilution effect promoted by high concentration of urea which triggered a rapid and vigorous vegetative growth, which also seem to be occurring in epiphytic cacti (Spironello et al., 2004). The highest $\mathrm{P}$ content in joints was 7.7 $\mathrm{g} / \mathrm{kg}$ at dose of $33.3 \mathrm{mM} \mathrm{N}$ in Rhipsalis baccifera, whereas for $R$. paradoxa and $H$. salicornioides the contents decreased with an increase of urea in HA solution. Contents of S showed small variation for species $R$. baccifera and $R$. paradoxa and decreased in $H$. salicornioides with the increase of $\mathrm{N}$ concentration in HA.

B contents in $R$. baccifera, increased $40 \%$ and accumulated $25 \%$ more $\mathrm{Cu}$ in highest doses of $\mathrm{N}$, when compared to control, whereas in $H$. salicornioides, $\mathrm{Cu}$ and $\mathrm{B}$ contents increased $100 \%$ and $36 \%$ respectively, with the increase of $\mathrm{N}$ dose in HA solution, differently from $R$. paradoxa which reduced $\mathrm{B}$ content, according to the tendency observed in
Mulder diagram, modified by Malavolta (1980), in which the interaction is antagonistic. The dual behavior of the species studied seems to indicate that the absorption of $\mathrm{B}$ and $\mathrm{Cu}$ depending on $\mathrm{N}$ does not always follow the trend indicated in the Mulder diagram. In all the species, Fe and Mn contents in joints increased with increasing doses of $\mathrm{N}$ from 0 to $66.6 \mathrm{mM} \mathrm{N}$, except $\mathrm{Zn}$ which decreased in $R$. paradoxa. Zinc contents in joints of cacti $R$. baccifera and $H$. salicornioides did not alter, according to the increase of $\mathrm{N}$ dose, whereas, in $R$. paradoxa, $\mathrm{Zn}$ showed the lowest value (54 mg/kg) in dose $33.3 \mathrm{mM} \mathrm{N}$.

Plants with epiphytic habit of families Bromeliaceae and Orchidaceae, due to strategies of water and nutrient accumulation, may present roots, which have no absorption capacity, being restricted to the function of fixing to the substrate (Benzing, 1987). In this study, $R$. baccifera, $R$. paradoxa and $H$. salicornioides roots responded to nitrogen solution application, enhancing growth and biomass production, indicating that besides fixation, the roots also carried out the function of nutrient absorption.

Nitrogen fertilizer was efficient for the growth of the three species of epiphytic cacti studied. According to Spurway \& Thomas (1992), the epiphytic cacti should be cultivated in concentrations lower than $7.32 \mathrm{mM} \mathrm{N}$, since they require low nitrogen contents. Nevertheless, the results obtained in the present study allow to recommend 
the use of 30.05 to $66.60 \mathrm{mM} \mathrm{N}$ in nutrient solution for $R$. baccifera, $H$. salicornioides and $R$. paradoxa, which in this concentration range the epiphytic cacti showed the best growth and nutrient accumulation responses.

\section{ACKNOWLEDGMENT}

To CNPq (The National Council for Scientific and Technological Development) for the scholarship (306140/2012-8) granted for research productivity for Tavares, AR.

\section{REFERENCES}

ARAÚJO, AG; PASQUAL, M; RODRIGUES, FA; CARVALHO, JG; ZARRAGA, DZA. 2009. Fontes de nitrogênio no crescimento in vitro de plântulas de Cattleya loddigesii Lindl. (Orchidaceae). Acta Scientiarum 31: 35-39.

BAR TAL, A. 2011. The effects of nitrogen form on interactions with potassium. Switzerland: International Potash Institute. $35 \mathrm{p}$.

BAUER, D. 2006. Sinopse taxonômica de Cactaceae epífitas no Rio Grande do Sul, Brasil. Acta Botanica Brasilica 20: 225-239.

BENZING, DH. 1973. The monocotyledons: their evolution and comparative biology. I. Mineral nutrition and related phenomena in Bromeliaceae and Orchidaceae. The Quarterly Review of Biology 48: 277-290.

BENZING, DH. 1987. Vascular epiphytism: taxonomy participation and adaptative diversity. Annals of the Missouri Botanical Garden 74: 183-204.

CALVENTE, A. 2010. Filogênia molecular, evolução e sistemática de Rhipsalis
(Cactaceae). São Paulo: USP. 185p (Tese doutorado).

CARDOSO, JC. 2005. Espécies nativas: preocupação ambiental e alternativa econômica. Horticultura Brasileira 23: 2 (artigo de capa).

CORADIN, L; SIMINSKI, A; REIS, A. 2011. Espécies nativas da flora brasileira de valor econômico atual ou potencial: plantas para o futuro, região sul. Brasília: Ministério do Meio Ambiente. 934p.

FAQUIN, V. 2002. Diagnose do estado nutricional das plantas. Lavras: UFLA/FAEPE, 77p.

FRESCHI, L; RODRIGUES, MA; DOMINGUES, DS; PURGATTO, E; SLUYS, MA; MAGALHÃES, JR.; KAISER, WM; MERCIER, H. 2010. Nitric oxide mediates the hormonal control of Crassulacean acid metabolism expression in young pineapple plants. Plant Physiology 152: 1971-1985.

HOAGLAND, DR; ARNON, DL. 1950. The water culture method for growing plants without soil. California Agricultural Experimental Station. 31p. (Circular 347).

HUNT, DR; TAYLOR, N; CHARLES, G. 2006. The new cactus lexicon. Milborne: DH Books. 373p.

KERSTEN, RA. 2010. Epífitas vasculares histórico, participação taxonômica e aspectos relevantes, com ênfase na Mata Atlântica. Hoehnea 37: 9-38.

MALAVOLTA, E. 1980. Elementos de nutrição mineral de plantas. São Paulo: Editora Agronômica Ceres. 251p.

MERCIER,, H; KERBAUY, GB; SOTTA, B; MIGINIAC, E. 1997. Effects of $\mathrm{NO}_{3}^{-}, \mathrm{NH}_{4}^{+}$ and urea nutrition on endogenous levels of IAA and four cytokinins in two epiphytic bromeliads. Plant, Cell \& Environment 20: 387-392.

NERD, A; NOBEL, PS. 1995. Accumulation, partitioning, and assimilation of nitrogen in Opuntia ficus-indica. Journal of Plant Nutrition 18: 2533-2549.

NOBEL, PS. 2002. Cactus physiological ecology, emphasizing gas exchange of cactus fruits. Acta Horticulturae 581: 143-150.

NOBEL, PS; BARRERA, E. 2003. Tolerances and acclimation to low and high temperatures for cladodes, fruits and roots of a widely cultivated cactus, Opuntia ficus-indica. New Phytologist 157: 271-279.

NOBEL, PS; BARRERA, E. 2004. $\mathrm{CO}_{2}$ uptake by the cultivated hemiepiphytic cactus, Hylocereus undatus. Annals of Applied Biology 144: 1-8.

NOBEL, PS; RUSSELL, CE; FELKER, P; GALO, JM; ACUÑA, E. 1987. Nutrient relations and productivity of prickly pear cacti. Agronomy Journal 79: 550-555.

SOUZA, VC; LORENZI, H. 2000. Botânica Sistemática-Guia ilustrado para identificação das famílias fanerogamas nativas e exóticas do Brasil, baseado em APGII. Nova Odessa: Editora Plantarum. 674p.

SPIRONELLO, A; QUAGGIO, JA; TEIXEIRA, LAJ; FURLAN, PR; SIGRIST, JMM. 2004. Pineapple yield and fruit quality effected by NPK fertilization in a tropical soil. Revista Brasileira de Fruticultura 26: 155-159.

SPURWAY, MI; THOMAS, MB. 1992. The influence of watering, shading and nitrogen levels on the growth of Schlumbergera $\mathrm{x}$ buckleyi. Combined Proceedings International Plant Propagators Society 42: 297-303.

SPURWAY, MI; THOMAS, MB. 2001. Nutrition of container-grown Christmas cacti. Journal of Plant Nutrition 24: 767-78.

STANCATO, GC; AGUIAR, FFA; KANASHIRO, S; TAVARES, AR; CATHARINO, ELM; SILVEIRA, RBA. 2003. Rhipsalis grandiflora Haw. (Cactaceae) propagation by stem cuttings. Scientia Agricola 60: 651-656.

TAKAHASHI, CA; MERCIER, H. 2011. Nitrogen metabolism in leaves of a tank epiphytic bromeliad: characterization of a spatial and functional division. Journal of Plant Physiology 168: 1208-1216.

TAYLOR, NP. 1997. Cactaceae. In: Oldfield S (ed). Cactus and succulent plants. Cambridge: IUCN/SSC. p. 17-20. 